\title{
POPULATION DISTRIBUTION AND DENSITY CHANGING PATTERN IN SUMATERA UTARA
}

\author{
Nilasari Siagian \\ Program Studi Hukum Keluarga, Fakultas Syariah, IAIDU \\ Jl. Mahoni, Mekar Baru, Kisaran Barat, Asahan, Sumatera Utara, 21264, Indonesia \\ e-mail: nilasari@gmail.com
}

Received: 05 June 2021, Repaired: 04 August 2021, Approved: 05 August 2021

\begin{abstract}
Abstrak
Tujuan penelitian ini adalah untuk mengetahui distribusi kepadatan penduduk deskripsi dan pola perubahan di Sumatera Utara. Jenis penelitian ini adalah penelitian kepustakaan. Tehnik pengumpulan data dilakukan dengan memanfaatkan fasilitas yang ada di perpustakaan, seperti buku, majalah, dokumen, catatan data sekunder, data statistik atau penelitian kepustakaan murni yang terkait dengan obyek penelitian. Metode analisis deskriptif memberikan gambaran dan keterangan yang secara jelas, objektif, sistematis, analitis dan kritis mengenai distribusi dan kepadatan penduduk deskripsi: karakteristik spasial dan pola perubahan di Sumatera Utara. Langkah awal yang ditempuh dengan mengumpulkan data-data yang dibutuhkan, melakukan klasifikasi, deskripsi kemudian dianalisis. Hasil penelitian ini menjelaskan bahwa pola distribusi dan kepadatan penduduk yang terjadi disebabkan oleh karakteristik spasial dan perubahanperubahan geologi. Jika dilihat dari aspek kepadatan penduduk. Tingginya kepadatan penduduk di Sumatera Utara menyebabkan masalah-masalah sosial seperti pengangguran, kemacetan, kemiskinan, rendahnya pelayanan kesehatan, meningkatnya angka kriminalitas, pemukiman kumuh, lingkungan tempat tinggal yang tidak sehat, dan lainnya. Pola distribusi penduduk yang terjadi adalah secara geografis. Penyebaran penduduk terbesar masih terkonsentrasi pada wilayah Pantai Timur, yaitu dimana pada wilayah tersebut terdapat sejumlah kabupaten yang berpenghuni terbesar (di atas $5 \%$ dari seluruh penduduk provinsi).
\end{abstract}

Kata kunci: Penduduk, Distribusi, Kepadatan, Spasial

\begin{abstract}
The purpose of this study was to determine the distribution of population density descriptions and patterns of change in North Sumatra. This type of research is library research. Data collection techniques are carried out by utilizing existing facilities in the library, such as books, magazines, documents, secondary data records, statistical data, or pure library research related to the object of research. The analytical method provides a clear, objective, systematic, analytical, and critical description and description of the distribution and population density description: characteristics and patterns of change in North Sumatra. The initial step is achieved by collecting the required data, classifying it, describing it, and then analyzing it. The results of this study explain that the distribution pattern and population density that occur are caused by spatial characteristics and geological changes. When viewed from the aspect of population density. The high population density in North Sumatra causes social problems such as congestion, poverty, health services, crime rates, settlements, unhealthy living environments, and others. The pattern of population distribution that occurs is geographical. The largest distribution is still throughout the East Coast region, wherein that region there are the largest number of districts (above $5 \%$ of the province's population).
\end{abstract}

Keywords: Population, Distribution, Density, Spatial 


\section{INTRODUCTION}

The demographic aspect greatly determines the composition of human beings in a region. In addition, residential modes, urban and rural population trends, components of population change (including studies of mortality, fertility, and migration as effects of changes in distribution and density), and interrelationships between and between population characteristics and distribution and density are included (Başkan et al., 2017).

The population distribution factor is important to consider zoning. Population studies often focus on a portrait of the distribution of the population and the factors that influence population distribution (L. Chen et al., 2012). Population distribution is the composition of the population in a certain area according to the conditions and needs of the community (Kumar, 2015).

The main factors that determine population distribution are climate, landscape, topography, soil, energy and mineral resources, accessibility such as distance from the sea coast, natural ports, navigable rivers or canals, cultural factors, political boundaries, migration and trade controls, government policies, types of economic activity, technology including types of agriculture and means of transportation, social organization and last but not least, demographic factors such as changes in natural growth and migration. Poor physical conditions and lack of sufficient opportunities for livelihoods have been mainly responsible for deterring occupants in certain areas (Ribeiro et al., 2021).

Climatic conditions are perhaps the most important of all geographic influences on population distribution (Syazili \& Bakti, 2020). In addition to physical factors, there are also other factors such as social, demographic, economic, political, and historical factors that affect the distribution of the population. Changes in population within a country have various implications (Putri et al., 2020). For example, different geographic, demographic, and Econo-social factors seem to contribute to the migration decisions made by individual residents. Demography, particularly population change, has been the target of intensive research because of its economic and social implications (Malik \& Dewancker, 2018). A key factor shaping demographic dynamics is migration.

Migration decisions by residents are influenced by various factors including employment opportunities, cost of living, and climatic conditions (Aljoufie, 2021). Deriving estimates of the population at risk as a basis for policy evaluation (Balk et al., 2006).

In fact, humans may regard a particular area, which may differ from administrative units and have a certain finite but unknown size, as the spatial unit on which migration decisions are based (Romdhoni, 2020). If so, individuals can make decisions by considering their current living environment and/or migration destinations to a certain distance, resulting in overcrowding (Başkan et al., 2017).

Trends in population distribution are one of the most dynamic and policyrelevant dimensions of the contemporary demographic situation (R. Chen et al., 2020). Distribution of the population between states, then the balance shifts between metropolitan and nonmetropolitan (Purnama et al., 2020). Trends in areas classified by degree of remoteness (Hugo, 2002).

Several large cities in Indonesia are classified as very dense compared to their area(Pavlic et al., 2013). This high population density causes social problems such as unemployment, congestion, poverty, low health services, increasing crime rates, slum settlements, unhealthy living environments, and so on (Pavlic et al., 2013). Besides social problems, it also causes spatial problems such as reduced agricultural land, vacant land, and an increase in the number of settlements (Başkan, A. H., Zorba, E., \& Bayrakdar, 2017). 
This phenomenon also occurs in several regions in Indonesia, such as in North Sumatra Province. The problem of distribution and population density has become one of the regional development planning agendas as outlined in the Provincial RPJMD and RKPD. Seeing the current development and distribution pattern of the population reflects the existence of population and regional problems that must be addressed immediately. If we refer to the data released by the Central Statistics Agency of North Sumatra Province in 2020, the population of North Sumatra is $15,136,522$ people, with a population density of 207.40 people $/ \mathrm{km} 2$. The geographical location of North Sumatra consists of $1^{\circ}-4^{\circ}$ north latitude $98^{\circ}-100^{\circ}$ east longitude.

The province of North Sumatra stretches across the island of Sumatra between the Indian Ocean and the Malacca Strait. It is bordered by the province of Aceh in the northwest and the provinces of Riau and West Sumatra in the southeast. These conditions certainly have an influence on development, the increase in the number of settlements, and changes in the composition of the population.

The geographical characteristics of the North Sumatra region consist of coastal areas, lowlands, and highlands as well as the Bukit Barisan mountains that stretch in the middle from North to South. Regionally, North Sumatra Province is located in a strategic international shipping lane in the Malacca Strait which is close to Singapore, Malaysia, and Thailand. North Sumatra Province has a coastline of 1,300 $\mathrm{km}$. The length of the east coastline is 545 $\mathrm{km}$, the length of the west coastline is 375 $\mathrm{km}$ and the length of the coastline of Nias island is $380 \mathrm{~km}$. There are 419 islands, with 237 islands that already have names, with 6 islands in the East Coast region including Berhala Island as the outermost island bordering the Malacca Strait and the remaining 182 islands in the West Coast region with Wonga Island and Simuk Island as the outermost islands in the Coastal area West.
The relationship between demographic characteristics such as population density and distribution in the North Sumatra region has an impact on the economic and social activities of the community. Responding to these problems and phenomena, the researcher considers it important to review how the pattern of change and distribution of population density in North Sumatra is.

\section{RESEARCH METHOD}

In this study, the author uses a type of library research, which is a series of activities related to library data collection methods. According to (Moelong, 2008). Library research is research that uses methods to obtain information data by placing existing facilities in the library, such as books, magazines, documents, secondary data records, statistical data, or pure library research related to the object of research.

Furthermore, descriptive analysis was carried out. The descriptive analysis method provides a clear, objective, systematic, analytical, and critical description and description of the distribution pattern and population density description in North Sumatra. The first step is to collect the required data, classify it, and then analyze it.

\section{RESULTS AND DISUSSION}

Population Distribution in Sumatera Utara

Population distribution means the pattern of where people live and is uneven (Linard et al., 2012). Population distribution data obtained through means such as household registration do not reflect the actual distribution and people's behavior such data only reflect the geographic spatial distribution of the population. Conversely, data such as street demographic data can truly reflect the overall distribution of the population over a long period of time. The population distribution is also uneven in a country.

Locations with favorable conditions are generally more densely populated than locations in more 


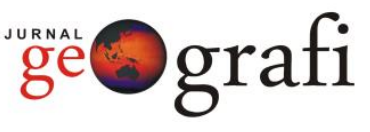

challenging environments (Hummel, 2020). North Sumatra Province is the fourth most populous province in Indonesia and the most populous province outside Java Island. Based on

Table 1. Total Population by Regency / City and Gender in 2020

\begin{tabular}{|c|c|c|c|c|}
\hline \multirow{2}{*}{ Regency/City } & \multicolumn{2}{|c|}{ Sex } & \multirow{2}{*}{ Amount } & \multirow{2}{*}{$\begin{array}{c}\text { Sex } \\
\text { Ratio }\end{array}$} \\
\hline & Male & Female & & \\
\hline Nias & 64.685 & 68.175 & 132.860 & 94,88 \\
\hline Mandailing Natal & 201.686 & 209.245 & 410.931 & 96,39 \\
\hline Tapanuli Selatan & 133.140 & 134.955 & 268.095 & 98,66 \\
\hline Tapanuli Tengah & 160.012 & 158.896 & 318.908 & 100,70 \\
\hline Tapanuli Utara & 140.238 & 143.633 & 283.871 & 97,64 \\
\hline Toba Samosir & 86.932 & 87.933 & 174.865 & 98,86 \\
\hline Labuhanbatu & 214.452 & 210.192 & 424.644 & 102,03 \\
\hline As a han & 340.302 & 337.574 & 677.876 & 100,81 \\
\hline Simalungun & 413.871 & 417.115 & 830.986 & 99,22 \\
\hline Dairi & 136.483 & 136.911 & 273.394 & 99,69 \\
\hline Karo & 178.073 & 180.750 & 358.823 & 98,52 \\
\hline Deli Serdang & 928.434 & 917.181 & 1.845 .615 & 101,23 \\
\hline Langkat & 492.424 & 484.461 & 976.885 & 101,64 \\
\hline Nias Selatan & 145.948 & 148.121 & 294.069 & 98,53 \\
\hline Humbang Hasundutan & 86.769 & 87.996 & 174.765 & 98,61 \\
\hline Pakpak Bharat & 20.938 & 20.554 & 41.492 & 101,87 \\
\hline Samosir & 60.384 & 61.210 & 121.594 & 98,65 \\
\hline Serdang Bedagai & 303.039 & 300.987 & 604.026 & 100,68 \\
\hline Batu Bara & 191.652 & 189.371 & 381.023 & 101,20 \\
\hline Padang Lawas Utara & 114.979 & 114.085 & 229.064 & 100,78 \\
\hline Padang Lawas & 116.289 & 115.877 & 232.166 & 100,36 \\
\hline Labuhanbatu Selatan & 145.214 & 139.595 & 284.809 & 104,03 \\
\hline Labuhanbatu Utara & 169.327 & 166.132 & 335.459 & 101,92 \\
\hline Nias Utara & 63.678 & 64.855 & 128.533 & 98,19 \\
\hline Nias Barat & 39.597 & 43.104 & 82.701 & 91,86 \\
\hline Sibolga & 43.036 & 42.816 & 85.852 & 100,51 \\
\hline Tanjungbalai & 79.202 & 77.973 & 157.175 & 101,58 \\
\hline Pematangsiantar & 115.488 & 121.459 & 236.947 & 95,08 \\
\hline Tebing Tinggi & 73.036 & 74.735 & 147.771 & 97,73 \\
\hline Meda $n$ & 1.047 .875 & 1.074 .929 & 2.122 .804 & 97,48 \\
\hline Binjai & 124.869 & 125.383 & 250.252 & 99,59 \\
\hline Padangsidimpuan & 96.841 & 101.968 & 198.809 & 94,97 \\
\hline Gunungsitoli & 62.793 & 65.544 & 128.337 & 95,80 \\
\hline Sumatera Utara & 6.591 .686 & 6.623 .715 & 13.215 .401 & 99,52 \\
\hline
\end{tabular}

Source: Badan Pusat Statistik Provinsi Sumatera Utara, 2020.

the projection results of the 2010 Population Census, the average population growth for $2010-2020$ is $1.28 \%$. The population of North Sumatra Provins in 2020 reached 14,799,361 people.
The sex ratio of the population of North Sumatra Province is 99.52, which means that the male population is less than the female population. The largest sex ratio is in South Labuhanbatu Regency, which is
104.03 and the smallest is in West Nias Regency, which is 91.86. From the data from the Population Census, the population growth rate of North Sumatra in 1990-2000 was $1.20 \%$ and in the period $2000-2010$, it 
increased to $1.22 \%$, which is the lowest population growth rate in Sumatra, or the 5th position of growth rate. the lowest population nationally (below the population growth rate of Central Java $(0.37 \%)$, East Java $(0.76 \%)$, West Kalimantan $(0.91 \%)$, and DI Jogyakarta (1.02\%).

Geographically, the largest population distribution is still concentrated in the East Coast region, where there are several districts with the largest population (above $5 \%$ of the entire province's population) and the highest density (above 200 people/ $\mathrm{km} 2$ ), such as Labuhan Batu, Asahan, Deli Serdang, Langkat and Serdang Bedagai. In this eastern region there are also many large cities with the largest distribution and population density, namely the cities of Medan, Sibolga, Tanjung Balai, Pematang Siantar, Tebing Tinggi, Medan, Binjai and Padang Sidempuan.

From the results of the 2010 Population Census, the distribution of the population of North Sumatra by district/city is below $5 \%$ on average, and only five districts/cities have a distribution above $5 \%$. In general, the gross density in North Sumatra Province is still low because most of the area is an undeveloped area, namely forest and plantation areas. Except for cities in North Sumatra, the density is relatively moderate as an urban area. Medan City, Deli Serdang Regency, and Langkat Regency are the three regencies/cities with the highest order having the largest population of 2,122,804 people $(16.06 \%), 1,845,615$ people $(13.97 \%)$, and 976,885 people (7.39\%). Meanwhile, Pakpak Bharat Regency is the district with the least population of 41,492 people $(0.31 \%)$.

\section{Density Population in North Sumatera}

Population density is a measure of the number of people in an area. This is an average number (Hummel, 2020). Population density is calculated by dividing the number of people by the area (Ratih, et al 2020) Population density is usually shown as the number of people per square kilometer. Of course, not everyone in a country is evenly distributed. Cities have a greater population density than rural areas (Yi Shi, Junyan Yang, and Peiyu Shen, 2020).

Density can also be used to refer to the number of plants or animals in each area. Sometimes, the population of animals or plants is too dense. This leads to overpopulation (Pequeno P, Mendel B, Rosa C, Bosholn M, Souza JL, Baccaro F, Barbosa $\mathrm{R}$, Magnusson W, 2020). With an area of about 71,680.68 square kilometers of North Sumatra Province inhabited by $13,215,401$ people, the average population density of North Sumatra Province is 184 people per square kilometer.

According to the latest population data in 2012, the regency/city with the highest population density level is Medan City, which is 8,008 people per square kilometer, while the lowest is Pakpak Bharat Regency with 34 people per square kilometer.

The second city with the highest density is Sibolga City at 7971 per square kilometer. With the limited land carrying capacity of Sibolga City while the population continues to grow, Sibolga City needs to control its population growth. For more details, see the following table:

Table. 2. Total Population, Density, and Population Distribution of Sumatera Utara by Kabupaten/Kota in 2020

\begin{tabular}{lrrr}
\hline \multicolumn{1}{c}{ Regency/City } & Amount & $\begin{array}{c}\text { Population } \\
\text { Density } / \mathrm{km}^{2}\end{array}$ & $\begin{array}{c}\text { Population } \\
\text { Distribution (\%) }\end{array}$ \\
\hline Nias & 132,860 & 136 & 1,01 \\
Mandailing Natal & 410,931 & 62 & 3,11 \\
Tapanuli Selatan & 268,095 & 62 & 2,03
\end{tabular}




\begin{tabular}{|c|c|c|c|}
\hline Tapanuli Tengah & 318,908 & 148 & 2,41 \\
\hline Tapanuli Utara & 283,871 & 75 & 2,15 \\
\hline Toba Samosir & 174,865 & 74 & 1,32 \\
\hline Labuhanbatu & 424,644 & 166 & 3,21 \\
\hline Asahan & 677,876 & 184 & 5,13 \\
\hline Simalungun & 830,986 & 190 & 6,29 \\
\hline $\mathrm{Da}$ i ri & 273,394 & 142 & 2,07 \\
\hline Ka ro & 358,823 & 169 & 2,72 \\
\hline Deli Serdang & $1,845,615$ & 742 & 13,97 \\
\hline Langkat & 976,885 & 156 & 7,39 \\
\hline Nias Selatan & 294,069 & 181 & 2,23 \\
\hline Humbang Hasundutan & 174,765 & 76 & 1,32 \\
\hline Pakpak Bharat & 41,492 & 34 & 0,31 \\
\hline Samosir & 121,594 & 50 & 0,92 \\
\hline Serdang Bedagai & 604,026 & 316 & 4,57 \\
\hline Batu Bara & 381,023 & 421 & 2,88 \\
\hline Padang Lawas Utara & 229,064 & 58 & 1,73 \\
\hline Padang Lawas & 232,166 & 60 & 1,76 \\
\hline Labuhanbatu Selatan & 284,809 & 91 & 2,16 \\
\hline Labuhanbatu Utara & 335,459 & 95 & 2,54 \\
\hline Nias Utara & 128,533 & 86 & 0,97 \\
\hline Nias Barat & 82,701 & 152 & 0,63 \\
\hline Sibolga & 85,852 & 7.971 & 0,65 \\
\hline Tanjungbalai & 157,175 & 2.555 & 1,19 \\
\hline Pematangsiantar & 236,947 & 2.963 & 1,79 \\
\hline Tebing Tinggi & 147,771 & 3.844 & 1,12 \\
\hline Medan & $2,122,804$ & 8.008 & 16,06 \\
\hline Binjai & 250,252 & 2.773 & 1,89 \\
\hline Padangsidimpuan & 198,809 & 1.734 & 1,50 \\
\hline Gunungsitoli & 128,337 & 273 & 0,97 \\
\hline Sumatera Utara & $13,215,401$ & 184 & 100,00 \\
\hline
\end{tabular}

Source: Badan Pusat Statistik Provinsi Sumatera Utara, 2020.

The development of Medan City, which is located in the eastern region, has an impact on adjacent districts, giving rise to increasingly dominant urban population growth, such as the districts of Deli Serdang and Serdang Bedagai, followed by Asahan, Batubara, Simalungun, Karo and Langkat districts. On the other hand, districts far from Medan have populations that are predominantly rural, such as the districts of South Nias, Nias, Humbang Hasundutan and South Tapanuli.

The population in the East Coast region is greater than the population living in the West Coast and Highlands areas, of course this has the effect of the shrinking agricultural land in the east coast which results in food security, environmental problems, employment and settlements (Mohammed Hamud et al., 2019). From the graph, the trend of population growth in the West Coast Region has begun to keep pace with population growth in the Highlands. This imbalance in population growth is also the result of uneven development throughout the Province of North Sumatra. This will certainly be a priority for North Sumatra Province to control the distribution of the population so that it is evenly distributed throughout the Province of North Sumatra through equitable infrastructure development. 


\section{Spatial Characteristics and Changing Pattern in Sumatera Utara}

Geologically, the North Sumatra

Province has complex structures and rocks and has experienced several collisions from tectonic processes because of its position at the confluence of the Eurasian plate in the east and the Australian plate in the west. This causes the formation of a series of fault lines, fractures, and folding accompanied by volcanic activity. The fault line passes through the North Sumatra route starting from the Alas-Karo segment and is approximately $390 \mathrm{~km}$ long and is a source of geological natural disasters in the form of earthquake centers on land, tsunamis, and triggers for volcanic eruptions and landslides. The fault line (subduction) on the West Coast along approximately $250 \mathrm{~km}$ is the epicenter of the earthquake on the seabed.

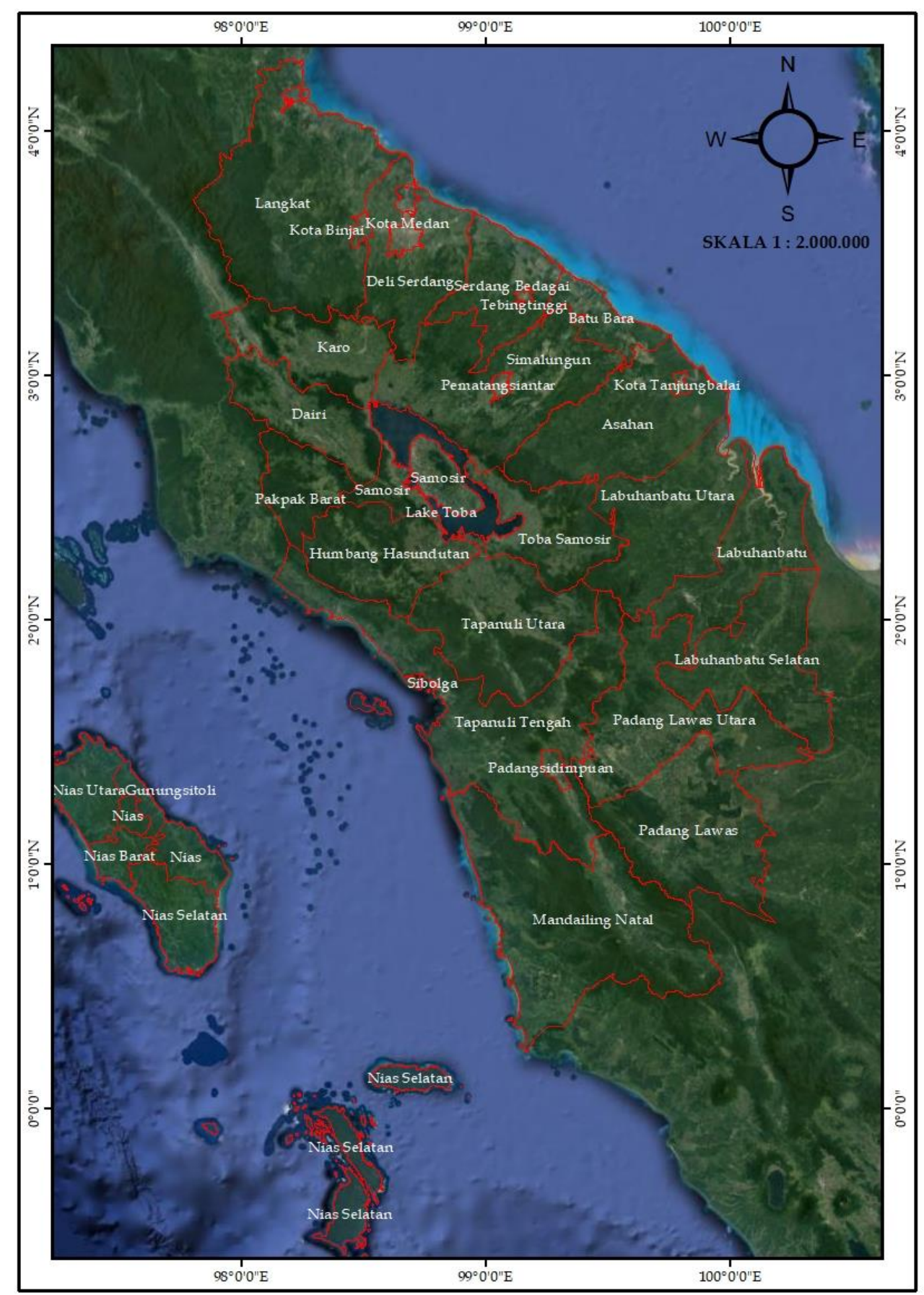

Figure 1. Administrative Map of Sumatera Utara 


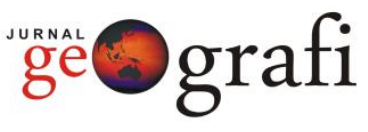

The condition of the complex geological structure which is characterized by the shape of the hilly landscape, folded with faults, apart from being an earthquake pathway, also has the potential to cause landslides in about $40-50 \%$ of the total area of North Sumatra Province which includes 18 districts and 1 city (according to the 2005 state of affairs), is an area that is prone to landslides. However, coastal areas are relatively in demand by the community for residence on the grounds that they can stimulate the economy. The coastal area is the boundary area between land and sea. The livelihoods of residents of coastal areas generally depend on marine exploitation, such as fishing, fishpond business, or making salt. Coastal community settlement areas generally follow an elongated pattern or a linear pattern along the coast (Gutiérrez Chacón et al., 2020).

Almost not much different from the settlement conditions of other coastal fishing communities, namely elongated or linear patterns along the coast. Residents in coastal areas have a relatively low economic level, wherein the west season, some fishermen do not go to sea and most of them only depend on fish in the sea. By looking at the above, it is necessary to make efforts to develop alternative livelihoods as one way that must be prioritized so that coastal residents are not concentrated in their places of residence during the west season.

Based on Figure 1 above, it can be explained that the North Sumatra region consists of coastal areas, lowlands and highlands as well as the Bukit Barisan mountains that stretch in the middle from North to South. The slope of the land is between $0-12 \%$ covering an area of $65.51 \%$, between $12-40 \%$ covering an area of $8.64 \%$, and above $40 \%$ covering an area of $24.28 \%$, while the area of Lake Toba is 112,920 hectares or $1.57 \%$. The altitude of the land in North Sumatra Province varies from $0-2,200 \mathrm{~m}$ above sea level. It is divided into 3 (three) parts, namely the eastern part which is relatively flat, the middle part is wavy to hilly and the western part is undulating plain.

The East Coast region which is a lowland area of $24,921.99 \mathrm{Km} 2$ or $34.77 \%$ of the total area of North Sumatra is a fertile area, high humidity with relatively high rainfall as well. Floods also often hit the area due to reduced forest conservation, erosion and river silting. In the dry season, there is also a shortage of water supply due to the critical condition of the forest. The highlands and the West Coast area of $46,758.69 \mathrm{~km} 2$ or $65.23 \%$ of the total area of North Sumatra, are mostly mountainous, have variations in soil fertility, climate, topography, and contours as well as areas with unstable soil structure. Several lakes, rivers, waterfalls, and volcanoes are found in this area and some areas are recorded as areas of tectonic and volcanic earthquakes.

\section{CONCLUSION}

North Sumatra Province ranks fourth with the largest population outside Java Island. The distribution patterns and population density that occur are caused by spatial characteristics and geological changes. When viewed from the aspect of population density. The high population density in North Sumatra causes social problems such as unemployment, congestion, poverty, low health services, increasing crime rates, slum settlements, unhealthy living environments, and others. The pattern of population distribution that occurs is geographically, the largest population distribution is still concentrated in the East Coast region, which is where there are a number of districts with the largest population (above $5 \%$ of the total population of the province). The spatial characteristics and patterns of change in the North Sumatra region consist of the coastal areas, lowlands and highlands as well as the Bukit Barisan mountains which stretch in the middle from North to South, so that these spatial characteristics determine the distribution of the population's residence. 


\section{REFERENCES LIST}

Balk, D. L., Deichmann, U., Yetman, G., Pozzi, F., Hay, S. I., \& Nelson, A. (2006). Determining Global Population Distribution: Methods, Applications and Data. Advances in Parasitology, 62(April), 119-156.

Başkan, A. H., Zorba, E., \& Bayrakdar, A. (2017). Impact of the population density on quality of life. Journal of Human Sciences, 14(1), 506.

Chen, L., Jie, F., \& Wẹi, S. (2012). Population distribution and influencing factors based on ESDA. Chinese Journal of Population Resources and Environment, 10(3), 4753.

Chen, R., Yan, H., Liu, F., Du, W., \& Yang, Y. (2020). Multiple global population datasets: Differences and spatial distribution characteristics. ISPRS International Journal of Geo-Information, 9(11).

Gutiérrez Chacón, E., Moral-Benito, E., OtoPeralias, D., \& Ramos, R. (2020). The Spatial Distribution of Population in Spain: An Anomaly in European Perspective. SSRN Electronic Journal.

Hugo, G. (2002). Changing Patterns of Population Distribution in Australia. Journal of Population Research and NZ Population Review, Special ed. 2002, 121.

Hummel, D. (2020). The effects of population and housing density in urban areas on income in the United States. Local Economy, 35(1), 27-47.

Kumar, M. (2015). A Study of Population Distribution. Int J Latest Technol Eng Manag Appl Sci, IV(Iii), 24-28.

Linard, C., Gilbert, M., Snow, R. W., Noor, A. M., \& Tatem, A. J. (2012). Population distribution, settlement patterns and accessibility across Africa in 2010. PLoS ONE, 7(2).

Malik, I. B. I., \& Dewancker, B. J. (2018). Identification of population growth and distribution, based on urban zone functions. Sustainability (Switzerland), 10(4), 1-13.

Mohammed Hamud, A., Mobarak Prince, H., \& Zulhaidi Shafri, H. (2019).
Landuse/Landcover mapping and monitoring using Remote sensing and GIS with environmental integration. IOP Conference Series: Earth and Environmental Science, 357(1).

Pavlic, I., Portolan, A., \& Butorac, M. (2013). Urban tourism towards sustainable development. IJMBS (International Journal of Multidisciplinarity in Business and Science), 1(1), 72-79.

Purnama, H., Gunarto, T., \& Budiarty, I. (2020). Effects of energy consumption, economic growth and urbanization on indonesian environmental quality. International Journal of Energy Economics and Policy, 10(6), 580-587.

Putri, R. F., Abadi, A. W., \& Tastian, N. F. (2020). Impacts of Population Density for Landuse Assessment in Cengkareng, West Jakarta. Journal of Geoscience, Engineering, Environment, and Technology, 5(2), 56-67.

Ribeiro, H. V., Oehlers, M., MorenoMonroy, A. I., Kropp, J. P., \& Rybski, D. (2021). Association between population distribution and urban GDP scaling. PLoS ONE, 16(1 January), 1-15.

Romdhoni, M. F. (2020). The Use of Landsat Image and Census Data for Modelling Population Density and Urban Density in Palembang, Indonesia. Journal of Architectural Research and Design Studies, 4(2).

Syazili, A., \& Bakti, A. M. (2020). Population Distribution Information System in Tugumulyo District. Journal of Information Systems and Informatics, 2(1), 123-130.

Aljoufie, M. (2021). The Impact Assessment of Increasing Population Density on Jeddah Road Transportation Using Spatial Temporal Analysis. Sustainability, 35 (1445).

Başkan, A. H., Zorba, E., \& Bayrakdar, A. (2017). Impact of the population density on quality of life. Journal of Human Sciences, 14(1), 506-518,

Central Bureau of Statistics. (2020). North Sumatra Province in Figures 2020. North Sumatra Province: Central Bureau of Statistics 
Development Planning Agency at SubNational Level. 92018). Medium Term Regional Development Plan. North Sumatera: Development Planning Agency at Sub-National Level

Hummel. D. (2020). The effects of population and housing density in urban areas on income in the United States. Local Economy, Vol. 35(1) 27-47.

Pequeno P, Mendel B, Rosa C, Bosholn M, Souza JL, Baccaro F, Barbosa R, Magnusson W. (2020). Air transportation, population density and temperature predict the spread of COVID-19 in Brazil.

Ratih Fitria Putri, Aji Wijaya Abadi, Naufal Fattah Tastian. (2020). Impacts of Population Density for Landuse Assessment in Cengkareng, West Jakarta. Journal of Geoscience, e-ISSN: 2549-7057 | p-ISSN: 2085-8167

Engineering, Environment, and Technology, 5, (2), 56-67.

Yi Shi, Junyan Yang, and Peiyu Shen. (2020). Revealing the Correlation between Population Density and the Spatial Distribution of Urban Public Service Facilities with Mobile Phone Data. ISPRS International Journal of Geo-Information, 9, (38), 1-17. 